\title{
Processed and ultra-processed food consumption among children aged 13 to 35 months and associated factors
}

\author{
Consumo de alimentos processados e \\ ultraprocessados e fatores associados em \\ crianças entre 13 e 35 meses de idade
}

\author{
Consumo de alimentos procesados y \\ ultraprocesados y factores asociados en niños \\ entre 13 y 35 meses de edad
}

Mônica Araujo Batalha 1

Ana Karina Teixeira da Cunha França 2

Sueli Ismael Oliveira da Conceição 1

Alcione Miranda dos Santos 2

Francelena de Sousa Silva 1

Luana Lopes Padilha 1

Antônio Augusto Moura da Silva 2

\begin{abstract}
The aim of this study was to evaluate the consumption of processed and ultraprocessed foods among children aged 13-35 months and its associated factors. We studied 1,185 children within the BRISA cohort in São Luís, Maranhão State, Brazil. The food consumption was investigated using a 24-hour recall, and the percentages of daily caloric intake and nutrients were estimated by food groups according to "NOVA" classification. We chose to categorize children belonging to the upper tertile of the distribution as having a high consumption of processed and ultra-processed food products. The Poisson regression model with robust variance estimation using a hierarchical modeling approach was used to calculate the prevalence ratios (PRs) of variables associated with high consumption of processed and ultra-processed food products. The mean energy intake was 1,226Kcal/day. After adjustments, there was a higher proportion of high consumption of processed and ultra-processed food products among children whose mothers had $<12$ years of education and among children who were older than 16 months. Mothers with low schooling and children older than 16 months should be the targets of interventions aimed at reducing consumption of these food products and preventing adverse health outcomes in later life.
\end{abstract}

Industrialized Foods; Food Consumption; Child; Socioeconomics Factors

\author{
Correspondence \\ M. A. Batalha \\ Programa de Pós-graduação em Saúde Coletiva, Universidade \\ Federal do Maranhão. \\ Av. Barão de Itapary 227, São Luís, MA 65020-070, Brasil. \\ monicaabatalha@gmail.com \\ 1 Programa de Pós-graduação em Saúde Coletiva,Universidade \\ Federal do Maranhão, São Luís, Brasil. \\ 2 Departamento de Saúde Pública, Universidade Federal do \\ Maranhão, São Luís, Brasil.
}




\section{Introduction}

In recent decades, there has been a reversal of population dietary patterns, with reductions in the consumption of traditional foods and increases in foods that are ready for consumption 1,2 . This change has been associated to the occurrence of high prevalence of obesity worldwide ${ }^{3}$. In this context, a new classification of foods called "NOVA", which is based on the extent, order and type of processing used in their production, has been proposed 4 . NOVA is a valid tool for nutrition research and classifies all foods and food products into four groups: unprocessed or minimally processed foods, processed culinary ingredients, and processed and ultra-processed food products 4 .

Unprocessed foods are obtained directly from nature, from edible parts of plants and animals 5 . Minimally processed foods are natural foods modified by processes such as removal of inedible or unwanted parts, drying, pasteurization, freezing, without adding substances such as salt, sugar and oils to the original food 5. Processed culinary ingredients are substances obtained directly from the nature by processes such as pressing, refining, grinding and spray drying 5 .

Processed food products are made by adding sugar, oil and/or salt to unprocessed foods and the processes include various preservation or cooking methods. The main purpose of the manufacture of processed foods is to increase the durability of unprocessed foods 5 . The ultra-processed food products are industrial formulations that typically include substances not commonly used in culinary preparations, and additives whose purpose is to imitate sensory qualities of unprocessed foods 5 .

Processed and ultra-processed food products are characterized by having high energy density, greater amount of free sugar, sodium and saturated fat, and lower amounts of essential fibers and nutrients compared to unprocessed or minimally processed foods 5,6,7. When consumed in small amounts, these products are not harmful to health ${ }^{4}$. However, their high palatability and availability and the "aggressive" marketing of these products challenge their conscious consumption and make them preferred substitutes for unprocessed or minimally processed foods 8 . Another exacerbating factor is that the introduction of these products has been occurring very early in children's diets, even before 12 months of age 9 .

Attaining proper nutrition in the early years of life is critical to infant growth and development 10,11 and the dietary habits acquired early tend to persist not only into childhood but also into adulthood 12,13. There is strong evidence indicating that socioeconomic and demographic characteristics (such as maternal age and education, household income, children having older siblings) 14,15 and family life habits (such as parent nutrition knowledge and food parenting practices) play an important role in children's food preferences $16,17,18$.

Two studies observed a high contribution of ultra-processed food products to total caloric intake of children in the south of Brazil 19,20. One of those studies used a convenience sample of 204 children aged 2 to 10 years, among whom the average daily energy intake from these food products was $47 \% 19$. In that study, the higher the maternal education and the higher the child's age, the higher was the consumption of these food products 19 . To the best of our knowledge, that study was the only one that has investigated the factors associated with consumption of ultra-processed food products in childhood.

Considering the increased contribution of foods ready for consumption to individual's diets, the fact that habits started in childhood can last for a lifetime and are related to diseases in adulthood, and the gaps remaining in the knowledge of the consumption of processed/ultra-processed foods products in early ages, this study aimed to evaluate the consumption of processed and ultra-processed food products and investigate the factors associated with their consumption among children aged 13-35 months in the BRISA birth cohort, São Luís, Maranhão State, Brazil.

\section{Methods}

This was a cross-sectional study integrated within the prospective cohort study entitled Etiology of Preterm Birth and Consequences of Perinatal Outcomes for Child Health: Birth Cohorts in Two Brazilian Cities - BRISA, which was developed by the Federal University of Maranhão (UFMA) in partnership with the Ribeirão Preto Medical School, University of São Paulo (FMRP/USP). This study used data from the cohort in the city of São Luís, in which data collection occurred in two 
time periods: at birth, from January to December 2010, and at the second year of life, from April 2011 to January 2013.

\section{Population and study sample}

The birth cohort was established from a sample based on the number of hospital births recorded in São Luís in 2007 in the Brazilian Information System on Live Births (SINASC) of the Brazilian Ministry of Health. Detailed methods used in the birth cohort have been described in another publication 21. For this study, a subsample was selected from the BRISA birth cohort consisting of children from 13 to 35 months of age, whose food intake has been assessed.

Considering that the application of the tool used to assess food consumption in all children enrolled at birth would not be cost-effective, a random subsample was selected. This was composed of the sum of the number of preterm births, low birth weight babies and/or twins ( 853 children) and 1.5 times the number of term children, non-low birth weight babies and non-twins $(1,282)$, totaling 2,135 children. In this subsample, food intake has been assessed in 1,242 children, and there was a non-response rate of $41.8 \%$ (893 children). After excluding $4.6 \%$ of the children, whose food intake was atypical on the day that the 24 -hour food recall $(24 \mathrm{hR})$ was applied or whose mothers had refused to participate in the study, the final sample consisted of 1,185 children.

Children whose mothers reported that the $24 \mathrm{hR}$ was based on an atypical day by a negative answer to the question, "Yesterday, was the child fed as usual?", were excluded from this study, regardless of the reason.

The required minimum sample size was calculated using OpenEpi (http://www.openepi.com/), version $3.03 \mathrm{a}$, considering a type 1 error of $5 \%$, an $80 \%$ power, a ratio between the exposed and unexposed of 1 , and an odds ratio of 2; this resulted in an initial sample size of 422 children. Because this study was nested in a cohort study, the sample consisted of 1,185 children who participated in the birth cohort and had available data on their assessed food intake.

\section{Data collection}

In this study, data related to socioeconomics, demographics and behavioral factors, and anthropometric measures, were obtained through questionnaires administered at birth and in the follow-up phase at the second year of life. All interviews were conducted with mothers and/or guardians of the children from January 2010 to January 2013 by the team of researchers and trained interviewers.

Birthweight was measured when the child was unclothed, using an electronic Filizola Baby pediatric scale (Filizola, São Paulo, Brazil), For mothers, measurements of weight, using a Tanita digital scale and of height (Tanita, Arlington Heights, USA) with a portable Alturexata stadiometer (Alturaexata, Belo Horizonte, Brazil) were obtained with mothers barefooted, upright, feet together and with their arms along their body. To classify maternal nutritional status, the body mass index (BMI) was calculated using the cutoff points proposed by the World Health Organization (1995) 22.

Children's diets were evaluated using a $24 \mathrm{hR}$ into foods and drinks consumed the day before the interview. To standardize data collection, interviewers were trained in the application of the instruments. Regardless of the answer, the mother was asked for a detailed description of the food, preparation, and quantification of items consumed in household measures. A photo album was used to facilitate the recall of items consumed by the child the day before.

\section{Family, maternal and child characteristics}

The response variable was high consumption of processed and ultra-processed food products by children, categorized as yes or no. The independent variables were divided into hierarchical levels.

The first level included socioeconomic and demographic characteristics : maternal age $(<20$ years, 20-34 years, $\geq 35$ years); maternal education ( $\leq 8$ years, 9 to 11 years, $\geq 12$ years); maternal marital status (married, consensual union, without a partner); maternal remunerated activity (yes or no); number of people residing in the house (1-3, 4-5; > 5); family's socioeconomic class, according to the Brazilian Criteria of Economic Classification of the Brazilian Association of Research Companies (ABEP) 
(A/B, C or D/E, A comprising the better off and $\mathrm{E}$ those of lower income and education); child gender (male or female); and child's age (13-16 months, > 16-20 months and > 20-35 months). The second level included social and health assistance-related variables: beneficiary of the Bolsa Familia program (cash transfer) 23,24 (yes or no) and registered in the Family Health Strategy 25 (yes or no), obtained at 13-35 months by interview.

The third level comprehended maternal behavioral and reproductive characteristics: maternal smoking (yes or no); maternal consumption of alcohol (yes or no) and parity (primiparous or multiparous). The fourth level included child's birthweight $(\leq 2,500 \mathrm{~g} ;>2,500$ to $<4,000 \mathrm{~g} ; \geq 4,000 \mathrm{~g})$. The fifth level included the time of introduction of solids and semi-solids to the child's diet $(<6$ and $\geq 6$ month), and the sixth level was comprised of the current nutritional status of the mother, according to her body mass index, categorized as underweight $\left(<18.5 \mathrm{~kg} / \mathrm{m}^{2}\right)$, normal $\left(\geq 18.5\right.$ to $\left.<25 \mathrm{~kg} / \mathrm{m}^{2}\right)$ and excess weight, including overweight/obesity $\left(\geq 25 \mathrm{~kg} / \mathrm{m}^{2}\right)$.

\section{Statistical analysis}

\section{- Sampling}

As the sampling design was complex (all children who were born with low birth weight, preterm or twins and 1.5 times their number of controls) and also due to the non-response of children selected for the assessment of food consumption, the probability of follow-up for each category of variables was calculated. The variables that showed significant differences $(\mathrm{p}<0.05)$ in the probability of follow-up, according to the results of the chi-square test, were used to calculate the weighting factor. A logistic model with preterm birth, low birth weight and/or twinning, mother's education and socioeconomic class was performed to predict the likelihood of attendance for each child, and the weighting factor used corresponded to the inverse of the probability predicted by the model. Thus, all analyses were weighted by the inverse probability of selection, which accounted for the complex sampling design and for losses to follow-up.

\section{- Analysis of dietary data}

The Virtual Nutri Plus software version 2010 (http://52.67.123.48/VirtualNutri/Portal/Default. aspx) was used to calculate total calories and amounts of macronutrients and micronutrients, by the Brazilian food composition table (TACO) 26. For foods that did not have information regarding their composition in the software, labels of the products described by the mother were used instead. After this step, data were exported to Excel (Microsoft Corp., USA).

The use of a single $24 \mathrm{hR}$ may not represent the usual food consumption of individuals. Thus, Multiple Source Method (MSM; https://msm.dife.de/) version 1.0.1, was used to adjust food consumption for intrapersonal variability 27. This adjustment was made using a non-random subsample of 234 children with characteristics similar to the original sample and whose consumption was assessed for three $24 \mathrm{hR}$. A subsample of 234 children had at least an $80 \%$ power to detect if the estimated correlations between the replications of the $24 \mathrm{hR}$ for the compared foods or nutrients were significantly different from zero.

As many mothers had difficulty reporting information on the amount of milk ingested by the child during breastfeeding, and to prevent the loss of this information, a method proposed by Drewett et al. 28 was used. Using this method, the volume of breast milk consumed is estimated by the amount (in kilocalories) of complementary feeding, and by the child's age in days. This equation has been used in other studies in Brazil, such as one performed by Nejar et al. 29.

To analyze the percentage contribution of foods to the diet in terms of their processing, "NOVA classification" was used. This methodology was proposed by Monteiro et al. 4 and is formed by the following groups: unprocessed or minimally processed foods, processed culinary ingredients, processed and ultra-processed food products.

The calories from these groups for each child, based on the sum of the caloric intake of the foods reported in the $24 \mathrm{hR}$, were calculated later. In this study, we chose to use two groups: group 1 was composed of unprocessed or minimally processed foods and culinary preparations based on these 
foods, and group 2 consisted of processed and ultra-processed food products. The processed and ultra-processed food products were placed in the same group because they are both nutritionally unbalanced and the contribution of total caloric intake from processed foods was very low.

To estimate the contribution of processed and ultra-processed food products in relation to the total energy consumption, the "mean ratio" method was used. In this method, the distribution can be examined when the ratio varies between populations, and this ratio can be studied in relation to other variables. Moreover, the distribution of other factors provides summary statistics such as the median, percentile, and proportion of the population above or below a certain cutoff point.

In this study, we chose to categorize children belonging to the upper tertile of the distribution as having high consumption because, in literature, there is no cutoff point that classifies the consumption of processed and ultra-processed food products.

\section{- Data analysis}

We first performed a descriptive analysis of the characteristics of children and their families by absolute and relative frequencies, as well as the characteristics of food consumption of each food group in terms of the percentage contribution to total calories, macronutrients and micronutrients, based on the type of processing used in its manufacturing.

To identify the factors associated with a high intake of processed and ultra-processed food products, we designed a hierarchical theoretical model (Figure 1) and used Poisson regression with robust estimation of variance to calculate the prevalence ratios (PRs).

A bivariate analysis between the independent variables and the outcome within each hierarchical level was performed, and variables were only retained in the model if they had an unadjusted p-value less than 0.20 . For every hierarchical level, the variables within the same level were simultaneously introduced, and variables from previous levels that were significant were also included. In the final model, which was adjusted for significant variables selected in each level, only the variables that were significant at the 0.05 level were retained. Weighting factors were added to the model by means of the svyset commands. Statistical analyses were performed in Stata (Stata Corp LP, College Station, USA), version 12.0 , adopting a $95 \%$ confidence interval $(95 \% \mathrm{CI})$.

\section{Ethical aspects}

The study was approved by the Research Ethics Committee of the University Hospital of Federal University of Maranhão, under research protocol number 223/2009.

\section{Results}

We evaluated 1,185 children, who were predominantly male (51.2\%),with ages under or equal to 16 months (46.5\%). Approximately 9.5\% of the children had low birth weight and $17.9 \%$ had been introduced to solids and semi-solids before 6 months of age (Table 1).

In relation to the maternal characteristics, $70.1 \%$ of mothers were aged 20 to 34 years, $84 \%$ had more than 8 years of education and $67.3 \%$ did not have remunerated activity. There was a predominance of the socioeconomic class C (53.7\%) and families that were not registered in the Bolsa Familia program (68.6\%). Other maternal, family and child characteristics are shown in Table 1.

Regarding their energy intake, on average, children consumed $1,226 \mathrm{Kcal} /$ day. The proportion of processed and ultra-processed food products in terms of total calories was $25.8 \%$, and the remaining calories were from the group of unprocessed or minimally processed foods and culinary preparations (74.2\%) (Table 2).

Cow's milk was the item that contributed the most to the total calories consumed by children (28.6\%). Furthermore, in the group of unprocessed or minimally processed foods, significant caloric contributions from culinary preparations $(9.5 \%)$, rice (7.4\%), fruits and natural juices $(7.1 \%)$, beef (5.6\%) and poultry (4.4\%) were also observed. In the group of processed foods, bread (1.2\%) was the food item that contributed the most. Regarding the ultra-processed foods, baby products (10.9\%), petit 
Figure 1

Hierarchical model proposed to evaluate the association between high consumption of processed and ultra-processed food products and family characteristics among children aged 13-35 months. BRISA birth cohort, São Luís, Maranhão State, Brazil, 2010-2013.
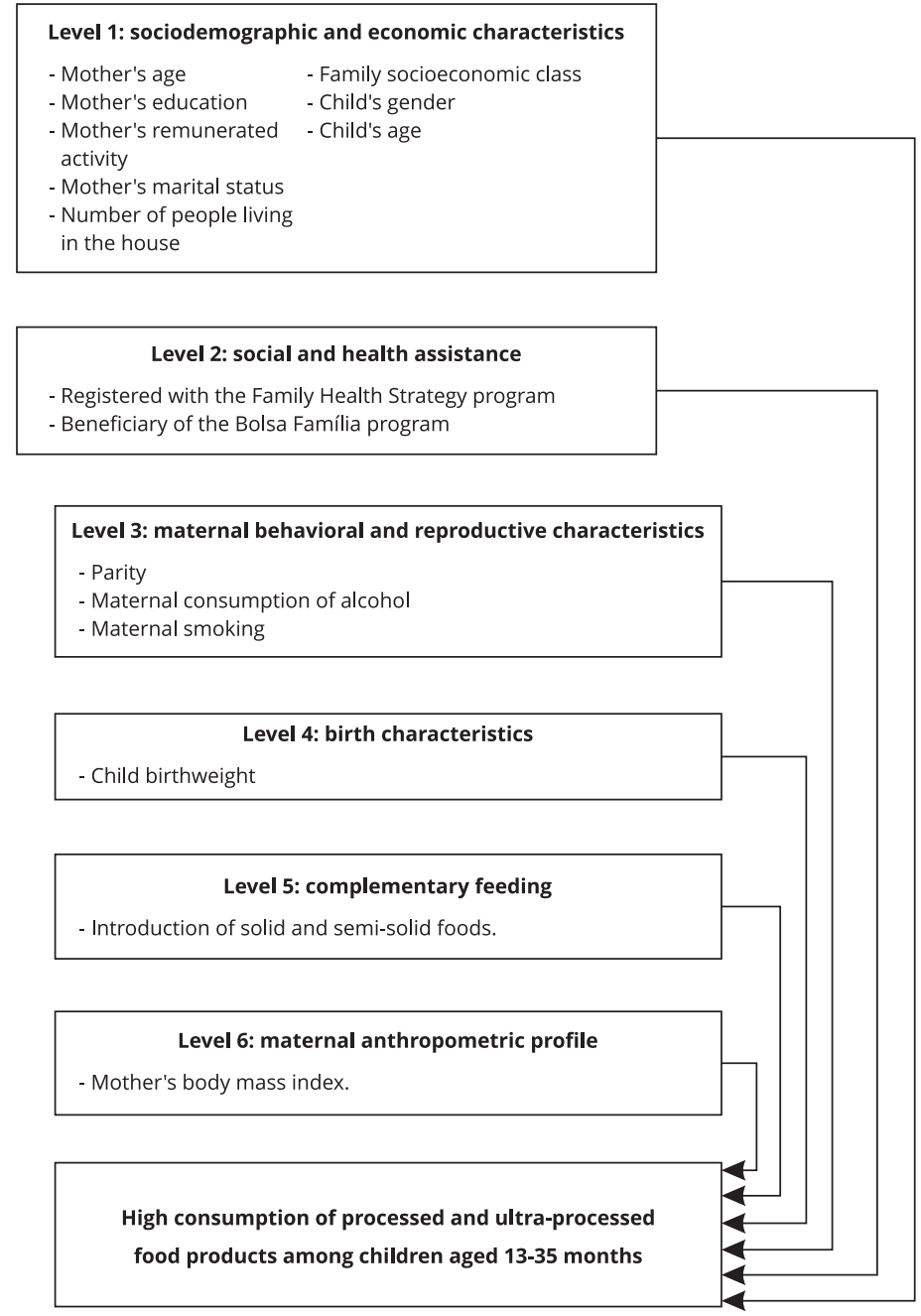

suisse cheese (3.7\%), cookies, pastries and cakes (2.3\%) and instant soups and noodles (1.9\%) contributed to the total daily calories consumed by the child (Table 2 ).

Table 3 shows the results of the evaluation of the diet consumed by children and percentages of food consumption. Compared to the group of unprocessed or minimally processed foods, the consumption percentage of processed and ultra-processed food products presented higher sodium content $(1,266.8 \mathrm{mg})$, higher levels of carbohydrates (54.4\%), total fat (32.5\%) and saturated fat (10.9\%), lower protein $(13.1 \%)$ and fiber content $(0.9 \mathrm{~g})$.

In the unadjusted analysis, high percentages of processed and ultra-processed food products consumption occurred among children aged 17 to 20 months ( $\mathrm{PR}=1.42$; 95\%CI: 1.15-1.76), 21 to 35 months ( $\mathrm{PR}=1.32 ; 95 \% \mathrm{CI}: 1.08-1.61)$ and among those whose mothers had up to eight years $(\mathrm{RP}=$ 1.37; 95\%CI: 1.08-1.73) and nine to eleven years of education (PR = 1.25; 95\%CI: 1.03-1.52) (Table 4). 
Table 1

Demographic, socioeconomic and behavioral characteristics of the families of children aged 13-35 months with estimated food consumption. BRISA birth cohort, São Luís, Maranhão State, Brazil, 2010-2013.

\begin{tabular}{|c|c|c|}
\hline Variables & $n$ * & $\%$ ** \\
\hline \multicolumn{3}{|l|}{ Maternal } \\
\hline \multicolumn{3}{|l|}{ Age (years) } \\
\hline$<20$ & 234 & 21.4 \\
\hline$\geq 20$ to 34 & 849 & 70.1 \\
\hline$\geq 35$ & 102 & 8.5 \\
\hline \multicolumn{3}{|c|}{ Education (years of school) } \\
\hline$\leq 8$ & 139 & 16.0 \\
\hline $9-11$ & 272 & 23.8 \\
\hline$\geq 12$ & 756 & 60.2 \\
\hline \multicolumn{3}{|l|}{ Marital status } \\
\hline Married & 251 & 20.8 \\
\hline Consensual union & 708 & 59.9 \\
\hline Without a partner & 226 & 19.3 \\
\hline \multicolumn{3}{|l|}{ Remunerated activity } \\
\hline No & 783 & 67.3 \\
\hline Yes & 402 & 32.7 \\
\hline \multicolumn{3}{|l|}{ Parity } \\
\hline Primiparous & 581 & 47.8 \\
\hline Multiparous & 604 & 52.2 \\
\hline \multicolumn{3}{|l|}{ Alcohol consumption } \\
\hline No & 919 & 77.9 \\
\hline Yes & 252 & 22.1 \\
\hline \multicolumn{3}{|l|}{ Smoking } \\
\hline No & 1128 & 95.9 \\
\hline Yes & 44 & 4.1 \\
\hline \multicolumn{3}{|l|}{ Body mass index } \\
\hline Underweight & 101 & 8.4 \\
\hline Normal weight & 621 & 54.2 \\
\hline Overweight/Obese & 442 & 37.4 \\
\hline \multicolumn{3}{|l|}{ Family } \\
\hline \multicolumn{3}{|c|}{ Socioeconomic class $* \star \star$} \\
\hline$A / B$ & 221 & 20.3 \\
\hline C & 696 & 53.7 \\
\hline $\mathrm{D} / \mathrm{E}$ & 268 & 26.0 \\
\hline \multicolumn{3}{|c|}{ Number of people residing in the house } \\
\hline $1-3$ & 595 & 48.5 \\
\hline $4-5$ & 368 & 31.6 \\
\hline$>5$ & 222 & 19.9 \\
\hline \multicolumn{3}{|c|}{ Beneficiary of the Bolsa Família program (cash transfer) } \\
\hline No & 822 & 68.6 \\
\hline Yes & 362 & 31.4 \\
\hline \multicolumn{3}{|c|}{ Registered with the Family Health Strategy } \\
\hline No & 935 & 78.5 \\
\hline Yes & 248 & 21.5 \\
\hline
\end{tabular}

(continues) 
Table 1 (continued)

\begin{tabular}{|c|c|c|}
\hline Variables & n * & $\%$ ** \\
\hline \multicolumn{3}{|l|}{ Child } \\
\hline \multicolumn{3}{|l|}{ Gender } \\
\hline Female & 578 & 48.8 \\
\hline Male & 607 & 51.2 \\
\hline \multicolumn{3}{|l|}{ Age (months) } \\
\hline 13 to $\leq 16$ & 563 & 46.5 \\
\hline$>16$ to $\leq 20$ & 249 & 21.5 \\
\hline$>20$ to 35 & 373 & 32.0 \\
\hline \multicolumn{3}{|l|}{ Child birthweight (g) } \\
\hline$\leq 2,500$ & 187 & 9.5 \\
\hline$>2,500$ to 3,999 & 930 & 84.0 \\
\hline$\geq 4,000$ & 68 & 6.5 \\
\hline \multicolumn{3}{|c|}{ Introduction of solid and semi-solid foods (months) } \\
\hline$\geq 6$ & 977 & 82.1 \\
\hline$<6$ & 208 & 17.9 \\
\hline
\end{tabular}

In the adjusted hierarchical analysis, a high intake of processed and ultra-processed food products remained associated with low maternal education and child's age higher than 16 months. The proportion of individuals with a high consumption of processed and ultra-processed food products increased by $24 \%$ in children whose mothers had $9-11$ years of schooling (PR $=1.24$; 95\%CI: 1.02 1.51 ) and by $32 \%$ for those with mothers with up to 8 years of education (PR $=1.32$; 95\%CI: $1.05-1.67)$, compared to children whose mothers had 12 or more years of schooling. A higher consumption of processed and ultra-processed food products was present among children aged 17 to 20 months (PR $=1.37$; 95\%CI: $1.10-1.70)$ and 21 to 35 months $(\mathrm{PR}=1.30 ; 95 \% \mathrm{CI}: 1.07-1.59)$ than among those who were up to 16 months of age (Table 4).

\section{Discussion}

The results of this study indicate that, on average, processed and ultra-processed food products contributed to more than a quarter of the total calories $(25.8 \%)$ consumed by children. The higher contribution of these food products to the children's diet was observed in children whose mothers had less than 12 years of education and among those older than 16 months.

Compared to our data, studies in the south of Brazil showed higher contributions of processed and ultra-processed food products to the children's diet 19,30. However, these studies, performed in the south of the country, included children of a higher age group and, thus, the consumption may have been influenced by other environmental factors to which they might have been exposed. Besides, it is also important to consider cultural and food diversities between regions within a country 31 . In accordance with the present findings, data from the Brazilian National Health Survey (2013) revealed a higher percentage of soft drink and artificial juice intake in the South (38.5\%) compared to the Northeast (25.5\%), by children younger than 2 years 32 .

The high contribution of infant and child food products observed in the group of processed and ultra-processed foods may be explained by their overly high consumption of cow's milk, as infant and child food products include thickeners used to prepare porridge. In line with these findings, porridge consumption before six months was found to be frequent in the Northeast of Brazil 33, demonstrating 


\section{Table2}

Absolute and relative consumption averages of foods by type of processing in children aged 13-35 months. BRISA birth cohort, São Luís, Maranhão State, Brazil, 2010-2013.

\begin{tabular}{|c|c|c|}
\hline Food groups & Kcal/day & Total energy intake (\%) \\
\hline Unprocessed or minimally processed foods and culinary preparations & 910.1 & 74.2 \\
\hline Eggs & 2.1 & 0.2 \\
\hline Coffee & 4.1 & 0.3 \\
\hline Beans & 9.0 & 0.7 \\
\hline Fish & 19.7 & 1.6 \\
\hline Breast milk & 20.5 & 1.7 \\
\hline Vegetables & 22.2 & 1.8 \\
\hline Other cereals * & 24.9 & 2.0 \\
\hline Roots and tubers & 40.7 & 3.3 \\
\hline Poultry & 54.5 & 4.4 \\
\hline Beef & 66.8 & 5.6 \\
\hline Fruits and natural juices & 87.4 & 7.1 \\
\hline Rice & 91.0 & 7.4 \\
\hline Other foods and culinary preparations ** & 116.9 & 9.5 \\
\hline Cow's milk & 350.3 & 28.6 \\
\hline Processed foods & 15.6 & 1.3 \\
\hline Salted meat & 0.2 & 0.0 \\
\hline Cheese & 0.2 & 0.0 \\
\hline Other $* * *$ & 0.3 & 0.0 \\
\hline Bread & 14.9 & 1.2 \\
\hline Ultra-processed foods & 300.3 & 24.5 \\
\hline Reconstituted meat products (sausage, ham) & 1.2 & 0.1 \\
\hline Fast food & 2.6 & 0.2 \\
\hline Bakery products & 8.2 & 0.7 \\
\hline Other \# & 9.2 & 0.7 \\
\hline Carbonated drinks and artificial fruit drinks & 14.3 & 1.2 \\
\hline Dairy-sweetened beverages & 15.9 & 1.3 \\
\hline Crackers and packaged snacks & 17.9 & 1.5 \\
\hline Instant soups and noodles & 23.1 & 1.9 \\
\hline Cookies (biscuits), pastries and cakes & 28.7 & 2.3 \\
\hline Petit suisse cheese & 45.2 & 3.7 \\
\hline Infant and child food products \#\# & 134.0 & 10.9 \\
\hline Total & $1,226.0$ & 100.0 \\
\hline
\end{tabular}

* Corn starch, oats, cassava flour, rice flour;

** Coconut water, nuts, savory culinary preparations;

*** Canned or bottled vegetables, fruits and legumes, canned fish;

\# Breakfast cereals, cereals bars, margarine and instant sauces;

\#\# Flour for porridge, baby food and industrialized soups, infant formulas.

the components of children's early eating habits in this region. In addition to infant and child food products, the substantial contribution of petit suisse cheese and sweet biscuits to total calories, both of which having a low nutritional value, can also be related to the extensive publicity surrounding the food targeted to the children 34 .

The unfavorable nutritional profile of processed and ultra-processed food products found in the children's diet, with high sodium and saturated fat content, as well as low fiber and protein levels, has been already observed in a previous national study 31 . The high sodium consumption is related 


\section{Table 3}

Contribution of food groups to total calories and nutrients consumed by children aged 13-35 months based on the type of processing used in their manufacturing. BRISA birth cohort, São Luís, Maranhão State, Brazil, 2010-2013.

\begin{tabular}{lccc}
\hline & Total food consumption & $\begin{array}{c}\text { Unprocessed or minimally } \\
\text { processed foods }\end{array}$ & $\begin{array}{c}\text { Processed and ultra- } \\
\text { processed foods }\end{array}$ \\
\hline $\begin{array}{l}\text { Sodium (mg/day) } \\
\quad \text { Absolute }\end{array}$ & 1627.2 & 360.4 & 1266.8 \\
$\%$ & 100.0 & 22.2 & 77.8 \\
Fiber (g/day) & & & 0.9 \\
Absolute & 6.8 & 5.9 & 13.2 \\
\% & 100.0 & 86.8 & \\
Contribution in total energy per group & & & 54.4 \\
Carbohydrate (\%) & 49.8 & 43.5 & 13.1 \\
Protein (\%) & 19.5 & 28.2 & 32.5 \\
Total fat (\%) & 30.8 & 28.3 & 10.9 \\
$\quad$ Saturated fat (\%) & 10.3 & 9.3 & \\
\hline
\end{tabular}

\section{Table 4}

Prevalence ratios in the unadjusted and adjusted hierarchical analyses of characteristics of children aged 13-35 months with a high consumption of processed and ultra-processed food products. BRISA birth cohort, São Luís, Maranhão State, Brazil, 2010-2013.

\begin{tabular}{|c|c|c|c|c|}
\hline \multirow[t]{2}{*}{ Variables } & \multicolumn{2}{|c|}{ Unadjusted } & \multicolumn{2}{|c|}{ Adjusted } \\
\hline & PR $(95 \% \mathrm{CI})$ & p-value & PR $(95 \% \mathrm{CI})$ & p-value \\
\hline \multicolumn{5}{|l|}{ Level 1} \\
\hline Mother's age (years) & & 0.07 & & \\
\hline$<20$ & $1.66(1.08-2.56)$ & & & \\
\hline $20-34$ & $1.54(1.02-2.31)$ & & & \\
\hline$\geq 35$ & 1.00 & & & \\
\hline Mother's education (years of school) & & $<0.01$ & & 0.03 \\
\hline$\leq 8$ & $1.37(1.08-1.73)$ & & $1.31(1.04-1.66)$ & \\
\hline $9-11$ & $1.25(1.03-1.52)$ & & $1.22(1.00-1.49)$ & \\
\hline$>12$ & 1.00 & & 11.00 & \\
\hline Mother's remunerated activity & & 0.12 & & \\
\hline No & 1.00 & & & \\
\hline Yes & $0.87(0.72-1.04)$ & & & \\
\hline Mother's marital status & & 0.36 & & \\
\hline Married & 1.00 & & & \\
\hline Consensual union & 1.17 (0.94-1.47) & & & \\
\hline Without a partner & $1.09(0.83-1.45)$ & & & \\
\hline Number of people residing in the house & & 0.05 & & \\
\hline 1 to 3 & $0.79(0.64-0.97)$ & & & \\
\hline 4 to 5 & $0.79(0.63-0.99)$ & & & \\
\hline$>5$ & 1.00 & & & \\
\hline Family socioeconomic class * & & 0.92 & & \\
\hline$A / B$ & 1.00 & & & \\
\hline C & $0.99(0.79-1.24)$ & & & \\
\hline $\mathrm{D} / \mathrm{E}$ & $1.03(0.80-1.34)$ & & & \\
\hline
\end{tabular}

(continues) 
Table 4 (continued)

\begin{tabular}{|c|c|c|c|c|}
\hline \multirow[t]{2}{*}{ Variables } & \multicolumn{2}{|c|}{ Unadjusted } & \multicolumn{2}{|c|}{ Adjusted } \\
\hline & PR $(95 \% \mathrm{Cl})$ & p-value & PR $(95 \% \mathrm{Cl})$ & p-value \\
\hline \multicolumn{5}{|l|}{ Level 1} \\
\hline Child gender & & 0.98 & & \\
\hline Female & 1.00 & & & \\
\hline Male & $1.00(0.85-1.19)$ & & & \\
\hline \multicolumn{5}{|l|}{ Child's age (in months) } \\
\hline 13 to $\leq 16$ & 1.00 & $<0.01$ & 1.00 & $<0.01$ \\
\hline$>16$ to $\leq 20$ & $1.42(1.15-1.76)$ & & $1.37(1.10-1.70)$ & \\
\hline$>20$ to 35 & $1.32(1.08-1.61)$ & & $1.30(1.07-1.59)$ & \\
\hline \multicolumn{5}{|l|}{ Level 2} \\
\hline \multicolumn{5}{|l|}{ Registered with the Family Health Strategy } \\
\hline No & 1.00 & 0.23 & & \\
\hline Yes & $1.13(0.92-1.37)$ & & & \\
\hline $\begin{array}{l}\text { Beneficiary of the Bolsa Familia program (cash } \\
\text { transfer) }\end{array}$ & & 0.83 & & \\
\hline No & 1.00 & & & \\
\hline Yes & $0.98(0.81-1.18)$ & & & \\
\hline \multicolumn{5}{|l|}{ Level 3} \\
\hline Parity & & 0.83 & & \\
\hline Primiparous & 1.00 & & & \\
\hline Multiparous & $1.02(0.86-1.21)$ & & & \\
\hline Maternal consumption of alcohol & & 0.09 & & \\
\hline No & 1.00 & & & \\
\hline Yes & $1.21(0.97-1.52)$ & & & \\
\hline Maternal smoking & & 0.43 & & \\
\hline No & 1.00 & & & \\
\hline Yes & $1.18(0.78-1.78)$ & & & \\
\hline \multicolumn{5}{|l|}{ Level 4} \\
\hline Child birthweight (g) & & 0.12 & & \\
\hline$\leq 2,500$ & $0.90(0.70-1.16)$ & & & \\
\hline$>2,500$ to $<4,000$ & 1.00 & & & \\
\hline$\geq 4,000$ & $1.31(0.98-1.76)$ & & & \\
\hline \multicolumn{5}{|l|}{ Level 5} \\
\hline Introduction of solid and semi-solid foods (months) & & 0.07 & & \\
\hline$\geq 6$ & 1.00 & & & \\
\hline$<6$ & $1.21(0.98-1.48)$ & & & \\
\hline \multicolumn{5}{|l|}{ Level 6} \\
\hline Mother's body mass index & & 0.97 & & \\
\hline Underweight & $1.03(0.76-1.41)$ & & & \\
\hline Normal weight & 1.00 & & & \\
\hline Overweight/Obese & $1.00(0.84-1.20)$ & & & \\
\hline
\end{tabular}

95\%Cl: 95\% confidence interval; PR: prevalence ratio.

* Socioeconomic class proposed by the Brazilian Association of Research Companies (ABEP; http://www.abep.org/) using the Economic Classification Criteria of Brazil.

Note: significant estimates are in bold $(p<0.05)$. 
to increased blood pressure and, consequently, increased risk of cardiovascular diseases 35 , whereas consumption of foods rich in fiber were modestly associated with reduced risk of obesity, type 2 diabetes, and cardiovascular diseases in later life ${ }^{36}$. In this context, high participation of ultra-processed food products in the children's diet has shown a negative impact on health and has been related to the occurrence of obesity in adolescents and adults 37 , metabolic syndrome in adolescents 38 , and changes in blood pressure 39 and lipid profile in children 30.

A comparison of the results of the variables associated with high consumption of processed and ultra-processed foods in the present study with other studies was difficult because few of them have used this classification of food groups, as it is relatively recent. Moreover, many of the existing studies were based on household food availability and consumption from household budget surveys within an older age group. It is worth noting that only two studies have been conducted to investigate the factors influencing consumption of processed and ultra-processed food products, one conducted with children 19 and the other with adults 6 .

In the present study, low maternal education was associated with high consumption of processed and ultra-processed food products. Similar results have been found in studies assessing foods that are part of the processed and ultra-processed food products group in Brazil 40 and other countries 41,42. Some authors suggest that low maternal education is associated with low purchasing power and lack of access to health information, which could possibly lead to unhealthy food choices for children 43,44,45. Moreover, considering the high prevalence of advertising of ultra-processed food products by the food industry throughout the media, mothers with more years of education may have a greater ability to discern between healthy and unhealthy foods 46 .

However, high maternal education is not always associated with better child food intake. Sparrenberger et al. 19 observed that high maternal education was associated with increased contribution of ultra- processed food products in the diets of children in the South of Brazil, even though these authors note that this association was weak in magnitude.

We found a higher proportion of consumption of processed and ultra-processed food products among children aged over 16 months. Possibly, as children age they become more susceptible to the influences of different environments they experienced, enabling food choices that were not healthy 19,47 .

In early childhood, the family represents the main social influence, but as children grow and start school, their teachers, peers and others in school, along with the media and other social leaders, may become more important influences 48. A systematic review showed that children's growth was also related to a longer time spent in front of the television 49 , and this exposure was associated with an excessive consumption of foods with a high energy density and low nutrient content 49,50,51.

The new dietary guideline for the Brazilian population recommends that processed foods should have their consumption limited and that ultra-processed foods products should be avoided 52 .

Regarding the strengths, this study becomes relevant in the local and global scenario, since it is one of the few to have evaluated the determinants of consumption of these nutritionally unbalanced products, considering this new classification, in a sample of children at an early age. Through the identification of characteristics associated with early feeding practices, this study could help in the elaboration of public policies that focus on infant feeding, especially to prevent obesity in early life.

The findings of this study need to be interpreted in light of some limitations. For one, the use of a single $24 \mathrm{hR}$ may underestimate or overestimate individual food consumption, thus not reflecting the true eating habits of children. However, in addition to the large sample size, we used the MSM to obtain a corrected estimate of food consumption by accounting for within-person variability to reduce this limitation. Another possible limitation would be the use of non-random subsample to adjust for intrapersonal variability of food consumption. However, we compared relevant characteristics (age of mothers, family's socioeconomic class and age of children) of the 1,185 sample with the non-random subsample by the chi-square test. No significant differences were observed between the subsample and the total study sample. Similar to other methods of evaluating food consumption, $24 \mathrm{hR}$ has its own limitations and biases, such as memory bias. To minimize the effects of these limitations, trainings were conducted with the interviewers, and they used photo albums during the $24 \mathrm{hR}$ interviews, aiming to standardize portion sizes. In terms of nutritional composition, the absence of a description of the percentage of sugar contained in processed and ultra-processed foods was due to a 
limitation of the software used to evaluate food consumption in this study. Considering the difficulty in measuring the volume of breast milk, which influences children's food consumption, we chose to estimate this volume by an equation 28 that has been validated and used in a previous study 29 . It is worth noting that sample losses in the study were weighted by the inverse of the probability of selection, thus aiming to minimize selection bias. Finally, despite being nested within a cohort, the crosssectional design prevents the establishment of causal relationships between the dependent variables and the outcome studied.

In conclusion, we found an important contribution of processed and ultra-processed foods to the total caloric intake of children aged 13 to 35 months. It is known that high consumption of those products adversely impacts children's diet, as this food group was characterized by a high carbohydrate, saturated fat and sodium content and low fiber and protein content, compared with unprocessed or minimally processed foods. A higher prevalence of processed and ultra-processed food consumption was found among children whose mothers had less than 12 years of education and among children older than 16 months compared to their counterparts. Thus, it is important that children whose mothers had low education or were older than 16 months be targeted for interventions aimed at strengthening the acquisition of healthy habits and preventing adverse health outcomes.

\section{Contributors}

M. A. Batalha performed the statistical analysis, interpreted the findings and wrote the manuscript. A. K. T. C. França and A. A. M. Silva assisted in the interpretation of the findings, revised and approved the final version of the manuscript. S. I. O. Conceição, A. M. Santos, F. S. Silva and L. L. Padilha assisted in the interpretation of the findings and contributed to the writing of the manuscript.

\section{Acknowledgments}

The authors thank the children, mothers and guardians who participated in this study. This study was supported by the Brazilian National Research Council (CNPq; process 471923/2011-7 and 561058/2015-5), the Foundation for Scientific Research and Development of Maranhão (FAPEMA; process 0035/2008), and the São Paulo Research Foundation (FAPESP; process 2008-53593-0).

\section{References}

1. Martins AP, Levy RB, Claro RM, Moubarac JC, Monteiro CA. Increased contribution of ultraprocessed food products in the Brazilian diet (1987-2009). Rev Saúde Pública 2013; 47:65665.

2. Popkin BM. Contemporary nutritional transition: determinants of diet and its impact on body composition. Proc Nutr Soc 2011; 70:8291.

3. Popkin BM, Slining MM. New dynamics in global obesity facing low and middle-income countries. Obes Rev 2013; 14:11-20.

4. Monteiro CA, Cannon G, Levy RB, Claro RM, Moubarac JC. The big issue for disease, good health, well-being. World Nutrition 2012; 3:527-69.

5. Monteiro CA, Cannon G, Levy RB, Moubarac JC, Jaime P, Martins AP, et al. NOVA. The star shines bright. World Nutrition 2016; 7:28-38.

6. Bielemann RM, Santos Motta JV, Minten GC, Horta BL, Gigante DP. Consumption of ultraprocessed foods and their impact on the diet of young adults. Rev Saúde Pública 2015; 49:28.

7. Barquera S, Campirano F, Bonvecchio A, Hernández-Barrera L, Rivera JA, Popkin BM. Caloric beverage consumption patterns in Mexican children. Nutr J 2010; 9:47.

8. Moodie R, Stuckler D, Monteiro C, Sheron N, Neal B, Thamarangsi T, et al. Profits and pandemics: prevention of harmful effects of tobacco, alcohol, and ultra-processed food and drink industries. Lancet 2013; 381:670-9. 
9. Longo-Silva G, Toloni MHDA, Menezes RCED, Asakura L, Oliveira MAA, Taddei JAAC. Ultra-processed foods: consumption among children at day-care centers and their classification according to Traffic Light Labelling system. Rev Nutr 2015; 28:543-53.

10. Trabulsi JC, Mennella JA. Diet, sensitive periods in flavour learning, and growth. Int Rev Psychiatry 2012; 24:219-30.

11. Caetano MC, Ortiz TTO, Silva SGLD, Souza FISD, Sarni ROS. Complementary feeding: inappropriate practices in infants. J Pediatr (Rio J.) 2010; 86:196-201.

12. Nicklaus S. The role of food experiences during early childhood in food pleasure learning. Appetite 2016; 104:3-9.

13. Nicklaus S, Remy E. Early origins of overeating: tracking between early food habits and later eating patterns. Curr Obes Rep 2013; 2:179-84.

14. Vilela S, Oliveira A, Pinto E, Moreira P, Barros $\mathrm{H}$, Lopes C. The influence of socioeconomic factors and family context on energy-dense food consumption among 2-year-old children. Eur J Clin Nutr 2014; 69:47-54.

15. Patrick H, Nicklas TA. A review of family and social determinants of children's eating patterns and diet quality. J Am Coll Nutr 2005; 24:83-92.

16. Barroso GS, Sichieri R, Salles-Costa R. Relationship of socio-economic factors and parental eating habits with children's food intake in a population-based study in a metropolitan area of Brazil. Public Health Nutr 2014; 17:15661.

17. Larsen JK, Hermans RC, Sleddens EF, Engels RC, Fisher JO, Kremers SP. How parental dietary behavior and food parenting practices affect children's dietary behavior. Interacting sources of influence? Appetite 2015; 89:246-57.

18. Peters J, Sinn N, Campbell K, Lynch J. Parental influences on the diets of 2-5-year-old children: systematic review of interventions. Early Child Dev Care 2012; 182:837-57.

19. Sparrenberger K, Friedrich RR, Schiffner MD, Schuch I, Wagner MB. Ultra-processed food consumption in children from a Basic Health Unit. J Pediatr (Rio J.) 2015; 91:535-42.

20. Louzada ML, Martins APB, Canella DS, Baraldi LG, Levy RB, Claro RM, et al. Ultra-processed foods and the nutritional dietary profile in Brazil. Rev Saúde Pública 2015; 49:38.

21. Silva AAMD, Batista RFL, Simões VMF, Thomaz EBAF, Ribeiro CCC, Lamy Filho F, et al. Changes in perinatal health in two birth cohorts (1997/1998 and 2010) in São Luís, Maranhão State, Brazil. Cad Saúde Pública 2015; 31:1437-50.

22. World Health Organization. Physical status: the use and interpretation of anthropometry. Geneva: World Health Organization; 1995. (WHO Technical Report Series, 854).

23. Silva MOS. O Bolsa Família: problematizando questões centrais na política de transferência de renda no Brasil. Ciênc Saúde Coletiva 2007; 12:1429-39.
24. Carmo AS, Almeida LM, Oliveira DR, Santos LC. Influence of the Bolsa Família program on nutritional status and food frequency of schoolchildren. J Pediatr (Rio J.) 2016; 92:381-7.

25. Ministério da Saúde. Política Nacional de Atenção Básica. Brasília: Ministério da Saúde; 2012.

26. Núcleo de Estudos e Pesquisas em Alimentação, Universidade Estadual de Campinas. Tabela brasileira de composição de alimentos. Campinas: Núcleo de Estudos e Pesquisas em Alimentação, Universidade Estadual de Campinas; 2011.

27. Harttig U, Haubrock J, Knuppel S, Boeing H, Consortium E. The MSM program: web-based statistics package for estimating usual dietary intake using the Multiple Source Method. Eur J Clin Nutr 2011; 65:87-91.

28. Drewett RF, Woolridge MW, Jackson DA, Imong SM, Mangklabruks A, Wongsawasdii L, et al. Relationships between nursing patterns, supplementary food intake and breast-milk intake in a rural Thai population. Early Hum Dev 1989; 20:13-23.

29. Nejar FF, Segall-Corrêa AM, Rea MF, Vianna RPT, Panigassi G. Padrões de aleitamento materno e adequação energética Cad Saúde Pública 2004; 20:64-71.

30. Rauber F, Campagnolo PD, Hoffman DJ, Vitolo MR. Consumption of ultra-processed food products and its effects on children's lipid profiles: a longitudinal study. Nutr Metab Cardiovasc Dis 2015; 25:116-22.

31. Departamento de Atenção Básica, Secretaria de Atenção à Saúde, Ministério da Saúde. Alimentos regionais brasileiros. 2a Ed. Brasília: Ministério da Saúde; 2015.

32. Instituto Brasileiro de Geografia e Estatística. Pesquisa Nacional de Saúde 2013: ciclos de vida. Rio de Janeiro: Instituto Brasileiro de Geografia e Estatística; 2015.

33. Saldiva SRDM, Venancio SI, Gouveia AGC, Castro AL, Escuder MM, Giugliani ER. Influência regional no consumo precoce de alimentos diferentes do leite materno em menores de seis meses residentes nas capitais brasileiras e Distrito Federal. Cad Saúde Pública 2011; 27:2253-62.

34. Mallarino C, Gómez LF, González-Zapata L, Cadena Y, Parra DC. Advertising of ultra-processed foods and beverages: children as a vulnerable population. Rev Saúde Pública 2013; 47:1006-10.

35. Strazzullo P, D’Elia L, Kandala N-B, Cappuccio FP. Salt intake, stroke, and cardiovascular disease: meta-analysis of prospective studies. BMJ 2009; 339:b4567.

36. Cho SS, Qi L, Fahey GC, Klurfeld DM. Consumption of cereal fiber, mixtures of whole grains and bran, and whole grains and risk reduction in type 2 diabetes, obesity, and cardiovascular disease. Am J Clin Nutr 2013; 98: 594-619. 
37. Louzada MLC, Baraldi LG, Steele EM, Martins APB, Canella DS, Moubarac JC, et al. Consumption of ultra-processed foods and obesity in Brazilian adolescents and adults. Prev Med 2015; 81:9-15.

38. Tavares LF, Fonseca SC, Garcia Rosa ML, Yokoo EM. Relationship between ultra-processed foods and metabolic syndrome in adolescents from a Brazilian Family Doctor Program. Public Health Nutr 2012; 15:82-7.

39. Vitolo MR, Louzada ML, Rauber F, Campagnolo PD. Risk fator for high blood pressure in low income children aged 3-4 years. Eur J Pediatr 2013; 172:1097-103.

40. Saldiva SR, Venancio SI, Santana AC, Silva Castro AL, Escuder MML, Giugliani ERJ. The consumption of unhealthy foods by Brazilian children is influenced by their mother's educational level. Nutr J 2014; 13:33.

41. Fernández-Alvira JM, Mouratidou T, Bammann K, Hebestreit A, Barba G, Sieri S, et al. Parental education and frequency of food consumption in European children: the IDEFICS study. Public Health Nutr 2013; 16:487-98.

42. Camara S, de Lauzon-Guillain B, Heude B, Charles MA, Botton J, Plancoulaine S, et al. Multidimensionality of the relationship between social status and dietary patterns in early childhood: longitudinal results from the French EDEN mother-child cohort. Int J Behav Nutr Phys Act 2015; 12:122.

43. Wijtzes AI, Jansen W, Jansen PW, Jaddoe VW, Hofman A, Raat H. Maternal educational level and preschool children's consumption of highcalorie snacks and sugar-containing beverages: Mediation by the family food environment. Prev Med 2013; 57:607-12.
44. Toloni MHDA, Longo-Silva G, Goulart RMM, Taddei JADAC. Introdução de alimentos industrializados e de alimentos de uso tradicional na dieta de crianças de creches públicas no município de São Paulo. Rev Nutr 2011; 24:61-70.

45. Toloni MHDA, Longo-Silva G, Konstantyner T, Taddei JADA. Consumption of industrialized food by infants attending child day care centers. Rev Paul Pediatr 2014; 32:37-42.

46. Molina MCB, Lopéz PM, Faria CP, Cade NV, Zandonade E. Preditores socioeconômicos da qualidade da alimentação de crianças. Rev Saúde Pública 2010; 44:785-92.

47. Bell LK, Golley RK, Magarey AM. Dietary risk scores of toddlers are associated with nutrient intakes and socio-demographic factors, but not weight status. Nutr Diet 2016; 73:73-80.

48. Pérez-Rodrigo C, Aranceta J. School-based nutrition education: lessons learned and new perspectives. Public Health Nutr 2001; 4:131-9.

49. Duch H, Fisher EM, Ensari I, Harrington A. Screen time use in children under 3 years old: a systematic review of correlates. Int J Behav Nutr Phys Act 2013 10:102.

50. Boyland EJ, Whalen R. Food advertising to children and its effects on diet: a review of recent prevalence and impact data. Pediatr Diabetes 2015 ; 16:331-7.

51. Boyland EJ, Halford JC. Television advertising and branding: effects on eating behaviour and food preferences in children. Appetite 2013; 62:236-41.

52. Departamento de Atenção Básica, Secretária de Atenção à Saúde, Ministério da Saúde. Guia alimentar para a população brasileira. Brasília: Ministério da Saúde; 2014. 


\section{Resumo}

O estudo teve como objetivo avaliar o consumo de alimentos processados e ultraprocessados por crianças entre 13 e 35 meses de idade e fatores associados. Estudamos 1.185 crianças da coorte BRISA em São Luís, Maranhão, Brasil. O consumo alimentar foi investigado com um recordatório de 24 horas, e os percentuais de ingestão diária de calorias e nutrientes foram estimados por grupos de alimentos de acordo com a classificação "NOVA". Optamos por categorizar as crianças pertencentes ao tercil superior da distribuição como tendo consumo elevado de produtos alimentícios processados e ultraprocessados. Foi utilizado um modelo de regressão Poisson com estimativa robusta de variância com modelagem hierárquica para calcular as razões de prevalência (RPs) das variáveis associadas ao consumo elevado de produtos alimentícios processados e ultraprocessados. A ingestão calórica média era 1.226Kcal/dia. Após os ajustes, houve uma proporção maior de consumo elevado de produtos alimentícios processados e ultraprocessados entre crianças cujas mães tinham menos de 12 anos de escola e entre crianças com mais de 16 meses de idade. As mães com baixa escolaridade e crianças acima de 16 meses devem ser alvos de intervenções para reduzir o consumo desses produtos alimentícios e prevenir os desfechos de saúde adversos na adolescência e idade adulta.

Alimentos Industrializados; Consumo de Alimentos; Criança; Fatores Socioeconômicos

\section{Resumen}

El objetivo de este estudio fue evaluar el consumo de alimentos procesados y ultraprocesados por parte de niños entre 13 y 35 meses de edad y sus factores asociados. Estudiamos a 1.185 niños de la cohorte BRISA en São Luís, Maranhão, Brasil. El consumo alimentario fue investigado con un recordatorio de 24 horas, $y$ los porcentajes de ingesta diaria de calorías y nutrientes fueron estimados por grupos de alimentos, de acuerdo con la clasificación "NOVA". Optamos por categorizar a los niños pertenecientes al tercil superior de la distribución como de consumo elevado de productos alimenticios procesados y ultraprocesados. Se utilizó un modelo de regresión Poisson de estimativa robusta de variancia con modelaje jerárquico para calcular las razones de prevalencia (RPs) de las variables asociadas al consumo elevado de productos alimenticios procesados y ultraprocesados. La ingesta calórica media era 1.226Kcal/día. Tras los ajustes, hubo una proporción mayor de consumo elevado de productos alimenticios procesados $y$ ultraprocesados entre niños, cuyas madres contaban con menos de 12 años de escuela y entre niños con más de 16 meses de edad. Las madres con baja escolaridad y niños por encima de 16 meses deben ser objetivo de intervenciones para reducir el consumo de esos productos alimenticios y prevenir desenlaces de salud adversos en la adolescencia y edad adulta.

Alimentos Industrializados; Consumo de Alimentos; Niño; Factores Socioeconómicos
Submitted on 29/Aug/2016

Final version resubmitted on 16/Dec/2016 Approved on 01/Feb/2017 